\title{
Pengembangan Aplikasi Berbasis Multimedia pada Pembelajaran Tematik Kelas III Sekolah Dasar
}

\author{
Faisal Azmi Bakhtiar
}

Pendidikan Dasar Pascasarjana Universitas Negeri Jakarta Jl. Rawamangun, RT.11/RW.14, Kota Jakarta Timur 13220 Email: faisalazmi648@gmail.com

\begin{tabular}{|c|c|}
\hline ABSTRACT & ABSTRAK \\
\hline $\begin{array}{l}\text { The purpose of this study is to analyze the } \\
\text { feasibility and practicality of multimedia-based } \\
\text { products on thematic learning of earth change } \\
\text { subtheme. This research was conducted on the } \\
\text { third-grade students of Elementary School with a } \\
\text { total number of } 156 \text { students as the respondents. } \\
\text { This research used research development (R \& D) } \\
\text { design of Dick, Carey and Carey model. To see } \\
\text { the effectiveness of the product developed by } \\
\text { the group field test with } 150 \text { students. Result of t- } \\
\text { test analysis showed tvalue =-8.97 <ttable = - } \\
\text { 1.962 at significance level a }=0,05 \text {. There was a } \\
\text { significant difference between the pre-test } 53.56 \\
\text { <post-test } 67.71 \text { and the difference of } 15.15 \text {. } \\
\text { These results showed that multimedia developed } \\
\text { effectively used in thematic learning. The results } \\
\text { of student responses showed an average score } \\
\text { of } 79.75 \% \text { Response analysis results can be } \\
\text { interpreted that multimedia-based applications } \\
\text { are worth it to apply. } \\
\text { Keywords: research and development, } \\
\text { multimedia, thematic, learning media, } \\
\text { elementary school. }\end{array}$ & 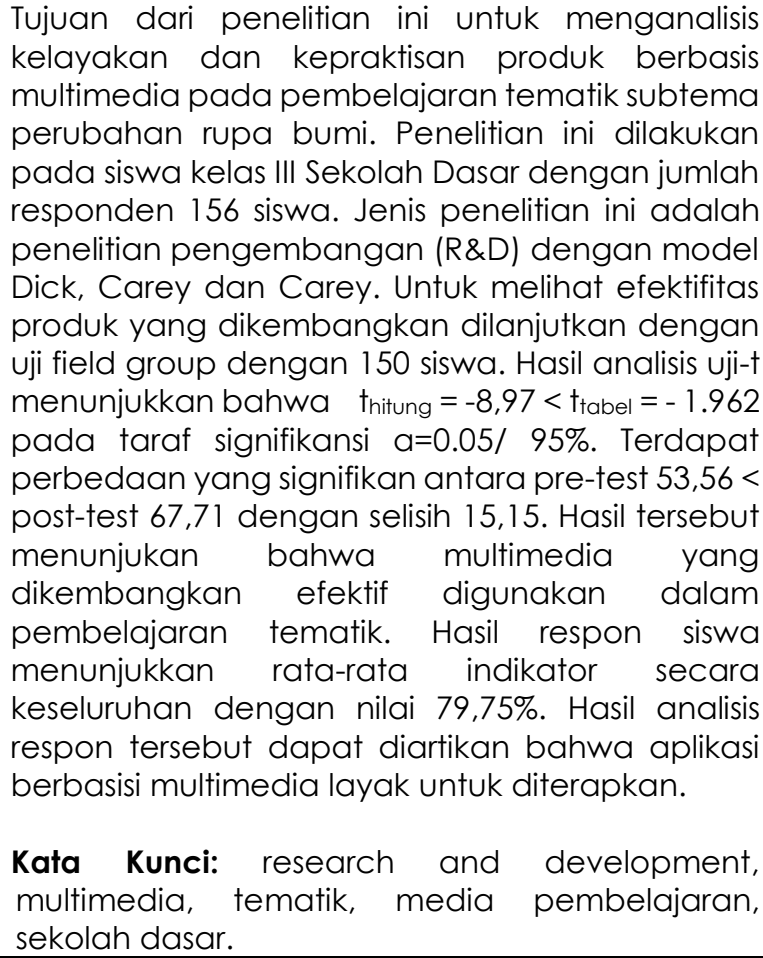 \\
\hline
\end{tabular}

How to Cite: Bakhtiar, F. (2018). Pengembangan Aplikasi Berbasis Multimedia pada Pembelajaran Tematik Kelas III Sekolah Dasar. Mimbar Sekolah Dasar, 5(1). 16-30. doi:http://dx.doi.org/10.17509/mimbar-sd.v5i1.9363.

PENDAHULUAN Pendidikan merupakan sebuah usaha membimbing, mengawasi, dan mengontrol oleh pendidik untuk membentuk peserta didik sesuai dengan tujuan yang telah ditetapkan. Sagala (2004, p. 4) menyebutkan bahwa pendidikan adalah proses dalam rangka memengaruhi peserta didik supaya mampu menyesuaikan diri sebaik mungkin dengan lingkungannya. Pendidikan bertumpu pada
4 pilar, yaitu learning to know, learning to do, learning to be, dan learning to live together (Unesco, 2017). Keempat pilar pendidikan tersebut dapat diterapkan secara optimal jika didukung dengan komponen-komponen pembelajaran. Basri (2013, p. 27) menyebutkan bahwa komponen-komponen pembelajaran, meliputi: (1) pendidikan dan perbuatan mendidik, (2) anak didik dan materi 
Faisal Azmi Bakhtiar, Pengembangan Aplikasi Berbasis Multimedia...

pendidikan, (3) dasar dan tujuan pendidikan, (4) metode pendidikan, (5) evaluasi pendidikan, (6) alat-alat pendidikan, dan (7) lingkungan pendidikan. Ketujuh komponen tersebut berpengaruh dalam meningkatkan kualitas pendidikan. Namun, terdapat beberapa komponen yang paling memengaruhi, yaitu peserta didik, pendidik, dan tujuan pendidikan. Ketiga komponen tersebut merupakan standar dasar dalam proses pembelajaran.

Kegiatan pembelajaran yang diterapkan pada kurikulum di Sekolah Dasar saat ini berproses pada model tematik integratif (terpadu). Pembelajaran terpadu menurut Muchtarom, Budimansyah \& Suryadi (2016, p. 155) dapat membentuk kepribadian utuh yang meliputi religiusitas, moralitas, intelektualitas, motivasi tinggi, kepemimpinan, gaya hidup sehat, kemandirian, etos kerja dan disiplin, serta kesadaran sosial-politik. Drăghicescu, Gorghiu, Gorghiu \& Petrescu (2013, p. 94) menyebutkan bahwa kurikulum terpadu merupakan karunia terbesar bagi guru yang berpengalaman, pendekatan tersebut membuat mengajar jauh lebih menarik dan berkontribusi dalam meingkatkan pendidikan di masa depan.

Dalam perjalanannya, model tematik terpadu yang digunakan di kelas satu sampai kelas enam sekolah dasar mengalami berbagai kendala dalam penerapannya. Munasik (2014, p. 112) menyebutkan bahwa guru sangat percaya bahwa pembelajaran tematik sangat bagus untuk meningkatkan kompetensi siswa, namun dalam penerapannya guru masih memiliki kesulitan. Penentuan metode dan media pembelajaran yang sesuai dengan tema masih menjadi masalah utama dalam penerapan pembelajaran tematik. Selain itu, Suwardi (2015, p. 272) juga menyebutkan bahwa kendala yang dihadapi dalam penerapan pembelajaran tematik adalah rendahnya kemampuan guru dalam merancang dan menerapkan pembelajaran tematik, dan kurangnya sarana prasarana yang mendukung dalam pembelajaran tematik.

Di sisi lain, ketika proses pembelajaran menggunakan model terpadu atau tematik mengalami berbagai kendala, terdapat media pembelajaran yang merupakan pendukung utama yang memiliki potensi dalam proses belajar mengajar. Aplikasi berbasis multimedia dipandang dapat mendukung pembelajaran tematik. Hal ini dibuktikan oleh penelitian Wua \& Yamanakab (2013, p. 303) yang menyebutkan bahwa penggunaan multimedia dalam pembelajaran dapat meningkatkan kepercayaan yang cukup tinggi terhadap hasil kerja siswa. Irlidiya, Tolla, Noni \& Anshari (2015, pp. 257-258) menyebutkan bahwa penggunaan multimedia interaktif untuk peningkatan kemampuan awal membaca di kelas rendah lebih efektif dan meningkat dengan baik dilihat dari aspek kelancaran, pengucapan, intonasi, dan suara. Ercan (2014: 618) menyebutkan bahwa teknologi di saat sekarang sudah begitu berkembang 
di setiap elemen masyarakat. Siswa generasi sekarang lebih positif dalam menanggapi multimedia di lingkungan sekitarnya. Pemanfaatan mutimedia dalam pembelajaran mampu mengubah perilaku dan meningkatkan hasil belajar siswa terutama dalam pelajaran sains. Záhorec, Hašková \& Bílek (2014, p. 377) dalam penelitiannya juga menyimpulkan bahwa multimedia mampu membantu guru dalam menghilangkan sifat negatif siswa terhadap mata pelajaran.

Untuk memperkuat hasil analisis literatur, peneliti melakukan analisis kebutuhan di Kecamatan Bumiayu Kabupaten Brebes. Hasil Survei dengan angket patokan ukuran skala Likert kategori Sangat lemah $10 \%$ 20\%), Lemah (21\% - 40\%), Cukup (41\% - 60\%), Kuat (61\% - 80\%), Sangat Kuat $(81 \%-100 \%)$ yang diberikan kepada 29 guru Sekolah Dasar di kecamatan Bumiayu Kabupaten Brebes menunjukkan hasil sebagai berikut:

Tabel 1. Hasil Analisis Angket Survei Kebutuhan

\begin{tabular}{cll}
\hline No & Instrument & Skor \\
\hline 1 & Pentingnya Pem. Tematik & $80 \%$ \\
2 & Kendala dalam Pem. Tematik & $76 \%$ \\
3 & Efektifitas Multimedia & $82 \%$ \\
4 & Perlunya Multimedia Tematik & $84 \%$ \\
5 & Guru \& Teknologi Multimedia & $86 \%$ \\
\hline
\end{tabular}

Analisis angket pada tabel 1 menunjukkan bahwa guru meyakini pembelajaran tematik memiliki peran yang sangat penting dalam pengembangan aspek pengetahuan, sikap, dan keterampilan anak. Namun dalam penerapannya guru masih terkendala dalam menentukan metode, media, dan proses pembelajarannya, baik dari segi perencanaan maupun kegiatan pembelajarannya. Sedangkan dari segi pemanfaatan aplikasi berbasis multimedia, guru sangat percaya bahwa multimedia efektif dalam berkontribusi mengembangkan sikap positif, motivasi, meningkatkan kemampuan membaca dan hasil belajar. Seiring dengan kemajuan teknologi, guru sangat setuju untuk mengembangkan kemampuan dalam penggunaan teknologi multimedia, baik dalam lingkup administrasi maupun kegiatan belajar mengajar. Untuk itu, responden dalam hal ini sangat antusias jika terdapat pengembangan aplikasi berbasis multimedia yang diterapkan pada pembelajaran tematik di Sekolah Dasar.

Survei lanjutan dilakukan untuk mengetahui kesukaran tema dan subtema pembelajaran tematik. Peneliti melakukan survei di daerah yang menggunakan pendekatan tematik dan kurikulum 2013 dalam pembelajarannya. Daerah yang di survei, yaitu di Kecamata Bumiayu Kabupaten Brebes Provinsi Jawa Tengah. Dalam survei ini guru kelas III diminta menulis empat subtema yang memiliki tiga kriteria, yaitu: (1) guru merasa kesulitan dalam mengajarkan tema atau sub tema tersebut; (2) dalam mengajarkan tema guru membutuhkan multimedia pembelajaran interaktif; (3) ketika pembelajaran menggunakan tema tersebut berlangsung, siswa mengalami penurunan motivasi dan minat belajar siswa rendah. Hasil survei menunjukkan bahwa terdapat dua tema yang paling banyak dipilih oleh guru kelas III 
Faisal Azmi Bakhtiar, Pengembangan Aplikasi Berbasis Multimedia...

Sekolah Dasar. Tema tersebut, yaitu tema perubahan di alam $22 \%$, dan tema bumi dan alam semesta $20 \%$. Jika dilihat dari subtema dalam pembelajaran tematik, prosentase tertinggi berada pada subtema perubahan rupa bumi sebesar $8 \%$ pada tema bumi dan alam semesta serta perubahan cuaca dan iklim sebesar $14 \%$ yang ada dalam tema perubahan di alam. Hasil analisis literatur dan survei lapangan, peneliti melihat bahwa terdapat potensi yang besar terhadap aplikasi atau program berbasis multimedia yang perlu dimanfaatkan dalam pembelajaran terpadu atau tematik subtema perubahan rupa bumi.

\section{METODE}

Penelitian ini bertujuan untuk menghasilkan aplikasi berbasis multimedia pada pembelajaran tematik di Sekolah Dasar. Bentuk produk yang dihasilkan berupa: (1) panduan guru dan siswa dalam pengoprasian aplikasi, dan (2) aplikasi berbasis multimedia dalam bentuk softfile. Penelitian pengembangan model ini juga untuk mengetahui bagaimana mengembangkan aplikasi berbasis multimedia interaktif pada pembelajaran tematik dan apakah aplikasi berbasis multimedia interaktif efektif diterapkan pada pembelajaran tematik untuk subtema perubahan rupa bumi siswa kelas III di Sekolah Dasar.

Penelitian ini dilaksanakan di Sekolah Dasar Kecamatan Bumiayu Kabupaten Brebes Provinsi Jawa Tengah. Sedangkan waktu penelitian dilaksanakan pada tahun ajaran 2016 - 2017. Metode penelitian dan pengembangan yang digunakan untuk medesain aplikasi berbasis multimedia pada pembelajaran tematik adalah model Gall, Gall \& Borg (2007). Menurutnya, untuk dapat mengembangkan program pembelajaran dapat digunakan model desain yang berorientasi pada sistem pembelajaran Dick, Carey \& Carey (2015, pp. 6-7).

Model pengembangan pembelajaran (instructional design system) Dick, Carey \& Carey yang berisi 10 tahapan atau langkah yaitu:

1. Identifikasi tujuan pembelajaran, menerapkan model desain sistem pembelajaran, dengan menentukan kemampuan atau kompetensi yang perlu dimiliki oleh siswa setelah menempuh program pembelajaran yang memanfaatkan aplikasi berbasis multimedia tersebut. Hal ini disebut dengan istilah instructional goals atau tujuan Instruksional. Peneliti memutuskan untuk membuat beberapa unit instruksi yang sesuai dengan tujuan awal. Dalam pembelajaran tematik subtema perubahan rupa bumi siswa akan: (a) mengikuti kegiatan pembelajaran tematik tema 8 subtema perubahan rupa bumi dengan bahan ajar berbasis multimedia secara aktif, kreatif, efektif, dan menyenangkan, dan (b) melakukan kegiatan sesuai prosedur pada pembelajaran tematik tema 8 
subtema perubahan rupa bumi dengan bahan ajar berbasis multimedia.

2. Melakukan analisis pembelajaran. Dalam melakukan analisis instruksional digunakan langkah-langkah untuk mengidentifikasi kompetensi, berupa pengetahuan, keterampilan, dan sikap yang perlu dimiliki siswa selama mengikuti program pembelajaran, yaitu: pengetahuan mengenai akibat dan penyebab perubahan rupa bumi, keterampilan fisk, dan sikap santun, peduli, dan tanggung jawab.

3. Menganalisis perilaku dan karakteristik awal peserta didik, analisis karakteristik siswa mencakup kamampuan aktual yang dimiliki siswa, gaya atau cara belajar dan sikap dalam aktivitas belajar. Analisis konteks mencakup kondisi-kondisi yang berkaitan dengan keterampilan yang dipelajari siswa dan situasi tugas yang dihadapi siswa untuk menerapkan pengetahuan dan keterampilan yag dipelajari.

4. Merumuskan tujuan pembelajaran. Berdasarkan hasil analisis instruksional, langkah selanjutnya adalah perlu mengembangkan kompetensi yang perlu dikuasai siswa untuk mencapai tujuan pembelajaran yang bersifat umum. Terdapat beberapa hal yang perlu diperhatikan dalam merumuskan tujuan pembelajaran secara spesifik, yaitu: (a) menentukan pengetahuan dan keterampilan yang perlu dimiliki siswa setelah menempuh KBM, (b) kondisi yang diperlukan agar siswa dapat melakukan unjuk kemampuan dari pengetahuan yang telah dipelajari, dan (c) merumuskan indikator yang dapat digunakan untuk mencapai keberhasilan siswa dalam menjalankan proses pembelajaran dengan aplikasi berbasis multimedia tersebut.

5. Mengembangkan instrument penilaian. Pada tahap ini, langkah yang ditempuh untuk memperoleh alat evaluasi untuk mengukur tingkat pencapaian kompetensi peserta didik yang ditetapkan dalam tujuan pembelajaran khusus. Instrument penilaian yang dikembangkan berdasarkan tujuan yang telah ditetapkan dan mengarahkan kepada keberhasilan siswa dalam pembelajaran pada subtema "Perubahan Rupa Bumi".

6. Mengembangkan strategi pembelajaran. Langkah berikutnya adalah dilakukan pengembangan strategi pembelajaran untuk mencapai tujuan akhir. Strategi pembelajaran yang dipilih dan akan digunakan, perlu diperhatikan berdasarkan beberapa faktor yaitu: (a) teori terbaru tentang aktifitas pembelajaran, (b) penelitian tentang hasil belajar, (c) kesesuaian dengan karakteristik media yang dikembangkan, dan (d) memerhatikan materi dan substansi yang akan diajarkan kepada siswa serta karakteristik siswa yang akan terlibat dalam kegiatan pembelajaran.

7. Mengembangkan dan memilih bahan ajar. Bahan ajar yang dikembangkan pada penelitian ini adalah aplikasi berbasis multimedia. Model yang 
Faisal Azmi Bakhtiar, Pengembangan Aplikasi Berbasis Multimedia...

digunakan dalam pengembangan aplikasi berbasis multimedia pada pembelajaran tematik di Sekolah Dasar adalah model Hybrid. Model multimedia pembelajaran tipe hybrid adalah model yang memadukan beberapa model multimedia lain sehingga menyajikan metode yang berbeda dan beragam. Model ini dipilih karena berbagai alasan yang melatarbelakanginya, yaitu: pembelajaran terpadu berbasis tematik yang memungkinkan kegiatan pembelajarannya sangat beragam; (2) meminimalisisr penggunaan sarana dan prasarana di sekolah; dan (3) memudahkan guru dalam penyampaian materi dan memotivasi siswa dalam kegiatan KBM.

8. Mendesain dan melaksanakan evaluasi formatif. Langkah selanjutnya setelah draf dan rancangan program pembeajaran selesai dikembangkan adalah melaksanakan evaluasi formatif. Evaluasi ini dilakukan untuk mendapatkan data terkait kelemahan dan kekuatan program pembelajaran. Hasil dari evaluasi ini dapat digunakan sebagai input untuk memperbaiki draf program. Tiga jenis evaluasi formatif dapat diaplikasikan untuk mengembangkan produk aplikasi berbasis multimedia pada pembelajaran tematik, yaitu: (1) uji perorangan (one-to-one), (2) uji kelompok kecil (small group), dan (3) uji lapangan (field evaluation).
9. Merevisi pembelajaran. Data dari evaluasi formatif yang telah dilakukan pada tahap sebelumnya dianalisis serta diinterpretasikan. Data yang diperoleh dari evaluasi formatif dikumpulkan dan diinterpretasikan untuk memecahkan kesulitan yang dihadapi warga belajar dalam mencapai tujuan. Evaluasi formatif tidak hanya pada produk pembelajarannya saja melainkan pada aspek-aspek desain sistem pembelajaran yang digunakan pada keseluruhan program. Pada dasarnya hasil evaluasi ini digunakan untuk merevisi pembelajaran agar lebih efektif. Tahap ini disebut juga sebagai tahap akhir dari pengembangan produk aplikasi berbasis mulitmedia pada pembelajaran tematik.

10. Mendesain dan melakukan evaluasi sumatif. Evaluasi sumatif dianggap sebagai langkah akhir atau puncak pengembangan desain instruksional yang berorientasi pada sistem yang mencakup produk pembelajaran oleh Dick, Carey \& Carey. Evaluasi sumatif dilakukan setelah program dievaluasi secara formatif kemudian direvisi dan sesuai dengan standar yang digunakan oleh perancang program yang meibatkan penilaian independen. Hal tersebut merupakan alasan untuk menyatakan bahwa pada tahap ini tidak termasuk dalam proses desain sistem pembelajaran. 


\section{HASIL DAN PEMBAHASAN}

Hasil tahapan pengembangan aplikasi berbasis multimedia pembelajaran tematik siswa kelas III Sekolah Dasar, yaitu:

\section{Pra-Produksi}

Sebelum melakukan tahap produksi yang lebih jauh, peneliti terlebih dahulu menganalisis kebutuhan dengan kuesioner dan studi literatur. Hasil tersebut disimpulkan bahwa multimedia adalah salah satu alternatif yang disukai oleh anak-anak dan memiliki potensi yang sangat besar untuk meningkatkan kualitas belajar dan mengajar. Kemudian peneliti mulai bekerja sama dengan berbagai pihak untuk menyelesaikan produk yang telah direncanakan. Pihak-pihak yang dibutuhkan meliputi pihak yang memiliki kemampuan untuk desain game baik melalui flash maupun media lain, pengisi suara dan editing gambar, animasi, video, dan suara.

\section{Produksi}

Aplikasi berbasis multimedia pembelajaran tematik ini menggunakan beberapa langkah utama, yakni pembuatan flowchart, storyboard, menyiapkan bahan, dan hyperlink.

1. Pembuatan flowchart, dan storyboard. Flowchart digunakan untuk mendesain model aplikasi multimedia yang digunakan, pada tahap ini model yang digunakan adalah model hybrid, yaitu gambungan model visual, audio, kuis, dan games. Sedangkan untuk storyboard digunakan untuk merancang tampilan atau visual dan percakapan di dalam aplikasi tersebut (audio), selain itu di dalam storyboard juga berisi tentang tata letak media yang akan digunakan seperti video, kuis, games, animasi dan lain sebagainya. Tahap ini dilakukan setelah desain instruksional telah dirancang meliputi penjabaran kompetensi inti, kompetensi dasar, indikator, dan tujuan yang di koordinasikan dengan materi ajar. Selain itu, rancangan pembelajaran juga segera diselesaikan yang meliputi silabus RPP dan alat evaluasi.

2. Pengumpulan bahan, tahap ini dibagi atas empat tahapan, yaitu membuat karakter, membuat background dan tombol, membuat bahan ajar, dan membuat suara. Pada tahap membuat karakter, dilakukan dengan beberapa aplikasi pendukung seperti FaceQ, MakeU dan MiniMe. Tahap selanjutnya adalah membuat background menggunakan Microsoft Power Point 2016, Adobe Photoshop, dan penggunaan beberapa gambar dari buku modul siswa Kementerian Pendidikan dan Kebudayaan. Untuk pembuatan media bahan ajar menggunakan aplikasi Ulead Video Studio, Total Video Converter, imgflip.com, dan beberapa gambar dan video yang diambil dari youtube dan google image. Sedangkan untuk pembuatan suara peneliti bekerjasama dengan beberapa orang dan 
Faisal Azmi Bakhtiar, Pengembangan Aplikasi Berbasis Multimedia...

selanjutnya diproses dengan pengubah suara, Music Maker Jam, dan Ulead.

3. Tahap akhir dari pengembangan produk adalah membuat mutimedia dengan Power Point Show, beberapa fitur digunakan untuk memaksimalkan bahan ajar ini seperti penggunaan trigger, hiperlink, action, audio, dan lain sebagainya. Pada proses ini peneliti bekerjasama dengan ahli flash agar aplikasi berjalan secara optimal. Dalam pengembangannya aplikasi selalu di putar ulang untuk melihat kelemahan yang ada pada aplikasi tersebut sebelum dilakukan uji ahli dan lapangan.

Tahap selanjutnya dari proses pengembangan aplikasi berbasis multimedia pada pembelajaran tematik adalah melakukan uji kelayakan. Uji tersebut dilakukan melalui tahapan expert review, one to one evaluation dan small group evaluation. Expert review yang dilibatkan terdiri dari ahli materi, ahli bahasa dan ahli media, dan guru SD kelas III. Tahap ini menggunakan penilaian skala Likert dengan Keterangan penilaian, yaitu: (a) 4.0 - 3,6 = Sangat Baik (Excellent), (b) 3.5 - $2.6=$ Baik (Good), (c) $2.5-2.0=$ Cukup (Sufficient), (d) $1.9-1.0=$ Kurang (Insufficient), dan (e) $0.9-0=$ Gagal (Fail).

Tabel 2. Hasil Penilaian Ahli Media

\begin{tabular}{lll}
\hline No. & Aspek & Nilai (Skala 4) \\
\hline 1 & Tampilan & 3,67 \\
2 & Kualitas & 3,67 \\
3 & Keterpaduan & 4 \\
4 & Pemrograman & 3,8 \\
\hline
\end{tabular}

Hasil penilaian media oleh ahli pada tabel 2 menunjukkan bahwa aspek tampilan, kualitas multimedia, keterpaduan antara konten, visual, audio, gambar, dan video serta aspek pemrograman dinyatakan sangat baik pada penilaian ahli media. Namun terdapat beberapa saran yaitu: (1) memerhatikan kesetaraan gander, dan (2) penggunaan karakter kartun yang beragam mulai dari perempuan, laki-laki, anak-anak, hingga orang dewasa pada multimedia yang dikembangkan. Saran tersebut sebagai acuan untuk dilakukan revisi dan pengecekan produk kembali sebelum dilakukan penilaian pada tahap berikutnya.

Tabel 3. Penilaian Ahli Ke-SDan Terhadap Multimedia

\begin{tabular}{lll}
\hline No. & Aspek & Nilai (Skala 4) \\
\hline 1 & Kesesuaian & 4 \\
2 & Kebaharuan & 3,5 \\
3 & Keakuratan & 3,2 \\
4 & Kelengkapan & 3 \\
5 & Pembelajaran & 3,4 \\
\hline
\end{tabular}

Hasil penilaian oleh ahli materi ke-SDan pada tabel 3 menunjukkan bahwa kesesuaian materi dengan tujuan instruksional dan karakteristik peserta didik dinilai sangat baik, sedangkan kebaruan materi pada multimedia pembelajaran, keakuratan materi dengan tujuan instruksional, karakteristik serta konsep, kelengkapan penyajian materi dengan visual dan audio, aspek pembelajaran antara pendidik, multimedia dan peserta didik dinilai baik. Secara keseluruhan bahan pembelajaran tematik berbasis multimedia baik dan layak untuk diterapkan di Sekolah Dasar dengan beberapa perbaikan, yaitu: 
(1) memerhatikan kualitas suara pada multimedia yang dikembangkan, penggunaan warna-warna dasar yang tidak menimbulkan gangguan perhatian pada siswa saat kegiatan KBM, dan (3) memerhatikan penggunaan huruf pada media yang dikembangkan.

Tabel 4. Penilaian Ahli Bahasa Terhadap Multimedia

\begin{tabular}{lll}
\hline No. & Aspek & Nilai (Skala 4) \\
\hline 1 & Kesesuaian & 3,75 \\
2 & Kebahasaan & 3,67 \\
\hline
\end{tabular}

Hasil penilaian pada tabel 4 di atas menunjukkan bahwa kesesuaian bahasa dengan perkembangan anak usia Sekolah Dasar dan aspek kebahasaan meliputi penggunaan kata, kalimat, dan paragraf dinilai sangat baik dalam pengembangan aplikasi berbasis multimedia pada pembelajaran tematik dan sangat layak diterapkan di lapangan. Terdapat beberapa saran dan perbaikan yaitu: (1) mencermati setiap ejaan setiap kata pada multimedia yang dikembangkan, (2) menyesuaikan dengan ejaan yang disempurnakan, dan (3) mengkaji kembali kesantunan kata ganti orang kedua yaitu "kamu" yang digunakan di buku modul kurikulum nasional dan multimedia yang digunakan.

Secara keseluruhan dapat dilihat nilai pada penilaian ahli untuk uji kelayakan draft ke-1 sebelum dilakukan uji kelayakan draft ke-2 pada tabel berikut.
Tabel 5. Penilaian Ahli

\begin{tabular}{lll}
\hline No. & Aspek & Nilai (Skala 4) \\
\hline 1 & Materi Ke-SDan & 3.42 \\
2 & Bahasa & 3.71 \\
3 & Media & 3.79 \\
\hline
\end{tabular}

Hasil penilaian oleh ahli pada tabel 5 menunjukkan bahwa materi yang ada dalam multimedia secara keseluruhan memperoleh nilai 3.4 tergolong baik, aspek kebahasaan 3.71 tergolong sangat baik, dan aspek media 3.79 tergolong sangat baik. Hasil penilaian oleh para ahli yang memiliki pengalaman dan gelar akademik di bidangnya menunjukkan bahwa aplikasi berbasis multimedia pada pembelajaran tematik sub tema perubahan rupa bumi untuk kelas III yang telah dikembangkan layak digunakan sebagai bahan ajar di sekolah menggunakan alat pendukung berupa laptop, LCD, Mouse, dan speaker.

Tahap selanjutnya yaitu uji kelayakan draft ke-2 yaitu: Uji one to one, small group, kontekstual, dan field group. Uji one to one pada evaluasi pengambangan multimedia ini dilakukan dengan teknik wawancara kepada dua orang siswa dengan kemampuan yang berbeda yaitu siswa yang memiliki prestasi rendah dan tinggi berdasarkan pilihan guru kelas. Hasil komentar siswa secara keseluruhan baik namun ada beberapa temuan dan masukan secara konstruktif. Penggunaan petunjuk kegiatan perlu diperjelas dan bahasa disesuaikan lagi dengan bahasa siswa. 
Faisal Azmi Bakhtiar, Pengembangan Aplikasi Berbasis Multimedia...

Uji small group dilakukan dengan teknik angket kepada 4 siswa yang sudah mengikuti kegiatan pembelajaran dengan multimedia tematik. Hasil penilaian meliputi efektivitas penyajian materi, konsep, tugastugas, dan evaluasi pada bahan pembelajaran tematik berbasis multimedia.

Tabel 6. Nilai Evaluasi Kelompok Kecil

\begin{tabular}{lll}
\hline No & \multicolumn{1}{c}{ Indikator } & Skala \\
\hline 1 & $\begin{array}{l}\text { Efektivitas penyajian materi, } \\
\text { konsep, tugas-tugas, dan } \\
\text { evaluasi pada bahan } \\
\text { pembelajaran tematik berbasis }\end{array}$ & 3,36 \\
& $\begin{array}{l}\text { multimedia. } \\
\text { Interaktivitas bahan } \\
\text { pembelajaran tematik berbasis } \\
\text { multimedia. }\end{array}$ & 3,36 \\
3 & $\begin{array}{l}\text { Kemenarikan bahan } \\
\text { pembelajaran tematik berbasis } \\
\text { multimedia. }\end{array}$ \\
\hline & $\begin{array}{l}\text { Efisiensi penggunaan bahan } \\
\text { pembelajaran tematik berbasis } \\
\text { multimedia. }\end{array}$ & 3,48 \\
\hline
\end{tabular}

Hasil penilaian small group pada tabel 6 , disetiap indikator dinyatakan baik. dari kegiatan di atas memperlihatkan, masih perlu adanya perbaikan pada bagian interaktivitas antara guru, siswa, dan bahan ajar tematik berbasis multimedia. Selain itu, pada bagian evaluasi dan tugas-tugas juga membutuhkan perbaikan baik dari segi kesukaran maupun petunjuk pembelajaran. Setelah dilakukan perbaikan-perbaikan, langkah selanjutnya adalah tahapan evaluasi lapangan.

Untuk meningkatkan kualitas produk, langkah selanjutnya adalah mengevaluasi produk oleh guru kelas tiga dengan observasi dan kuesioner. Saran dan masukan diperoleh dari beberapa guru di antaranya: (1) pemberian jeda di setiap kegiatan pada layar agar interaktif guru, murid, dan media menjadi lebih menarik dan tidak monoton, (2) memperbaiki video aku sayang bumiku agar disajikan dengan ukuran yang lebih besar, (3) memperbaiki kesalahan antara teks dan suara dan juga masalah pengetikan pada teks cerita, dan (4) multimedia harus menyediakan banyak kegiatan kepada siswa agar pembelajaran lebih aktif. Hasil penilaian kelayakan dapat dilihat pada tabel di bawah ini.

Tabel 7. Penilaian Guru Terhadap Multimedia

\begin{tabular}{clc}
\hline No. & \multicolumn{1}{c}{ Aspek } & Nilai (Skala 4) \\
\hline 1 & Kesesuaian & 3,6 \\
2 & Kebaharuan & 3,5 \\
3 & Keakuratan & 3,6 \\
4 & Kelengkapan & 3,6 \\
5 & Pembelajaran & 3,5 \\
\hline
\end{tabular}

Hasil penilaian kelayakan dalam bidang materi dan pembelajaran dapat dilihat pada tabel 7 bahwa aspek kebaharuan dan aspek pembelajaran dinilai baik, sedangkan aspek kesesuaian, keakuratan, dan kelengkapan dinilai sangat baik. Dapat disimpulkan bahwa secara keseluruhan guru menyatakan bahwa bahan ajar aplikasi berbasis multimedia pada pembelajaran tematik bagus dan layak untuk diaplikasikan dengan sedikit perbaikan.

Uji coba lapangan atau evaluasi lapangan ada dua macam, yaitu: (1) uji kesesuaian seperti kelompok kecil, dan (2) uji pretestpostest. Uji kelompok kecil telah dilakukan dan produk direvisi, selanjutnya adalah uji kelompok besar atau Uji efektivitas produk dilakukan terhadap 150 responden yang mengikuti pembelajaran tematik dari lima 
sekolah di Kecamatan Bumiayu Kabupaten Brebes. Uji coba dilakukan dengan tes hasil belajar melalui pre-test dan post-test yang dihitung menggunakan uji-†.

Tabel 8. Deskripsi Data

\begin{tabular}{lll}
\hline Keterangan & Pretest $\mathrm{x}_{1}$ & Postest $\mathrm{x}_{2}$ \\
\hline Jumlah & 7884 & 10156 \\
Rata-rata & 52,56 & 67,71 \\
Nilai tertinggi & 96,00 & 100,00 \\
Nilai Terendah & 8,00 & 20,00 \\
Standar Deviasi & 18,468 & 18,893 \\
Jumlah Responden & 150 & 150 \\
$\sum_{i=1}^{n} X_{i}^{2}$ & 465200 & \\
$\sum_{i=1}^{n} Y_{i}^{2}$ & & \\
$\sum_{i=1}^{n} X_{i} Y_{i}$ & & 740816 \\
\hline
\end{tabular}

Melalui tabel 8 di atas, dapat dipaparkan:

1. Hipotesis statistik:

a. $H_{0}=t_{\text {hitung }}<t_{\text {tabel }}=$ Tidak terdapat perbedaan yang signifikan antara pre-test dan post-test pada pembelajaran tematik berbasis multimedia subtema perubahan rupa bumi.

b. $\mathrm{H}_{1}=t_{\text {hitung }}>t_{\text {tabel }}=$ Terdapat perbedaan yang signifikan antara pre-test dan post-test pada pembelajaran tematik berbasis multimedia subtema perubahan rupa bumi.

2. Menyiapkan data pendukung untuk melakukan uji-†.

a. Nilai rata-rata pre-test $\left(\bar{X}_{1}\right)$, post-test $\left(\bar{X}_{2}\right)$. Nilai rata-rata untuk pretest: $\bar{X}_{1}=$ 52,56, dan post-test: $\bar{X}_{2}=67,71$

b. Standar deviasi pre-test $\left(s_{1}\right)=18,468$ , post-test $\left(s_{2}\right)=18,893$

C. Jumlah Responden $(n)=150$

d. Koefisien Korelasi $(r)=0,387$
3. Perhitungan Uji-t, rumus uji- $t$ yang digunakan adalah:

$$
t=\frac{\bar{X}_{1}-\bar{X}_{2}}{\sqrt{\frac{s_{1}^{2}}{n_{1}}+\frac{s_{2}^{2}}{n_{2}}-2 r\left(\frac{s_{1}}{\sqrt{n_{1}}}\right)\left(\frac{s_{2}}{\sqrt{n_{2}}}\right)}}
$$

4. Keputusan uji, hasil uji $\dagger$ menunjukan bahwa thitung $=-8,97$ dan tabel $=-1.962$ pada taraf signifikansi $a=0.05 / 95 \%$. Maka thitung $=-8,97<t_{\text {tabel }}=-1.962$, sehingga keputusan uji yang diambil adalah $\mathrm{H}_{0}=$ Ditolak

5. Kesimpulan, terdapat perbedaan yang signifikan antara pre-test dan post-test pada pembelajaran tematik berbasis multimedia subtema perubahan rupa bumi.

6. Gambar keputusan uji:

\section{Gambar 1. Keputusan Uji}

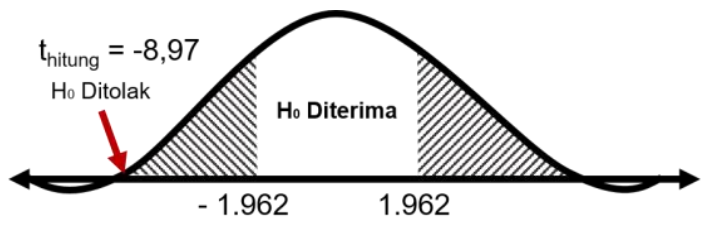

Berdasarkan analisis data pada gambar 1 di atas, dilihat perolehan nilai thitung $=-8,97<$ $t_{\text {tabel }}=-1.962$, pada taraf signifikansi $a=0.05 /$ kepercayaan 95\%. Dapat disimpulkan bahwa terdapat perbedaan hasil beajar siswa antara pre-test dan post-test, dengan demikian penggunaan aplikasi berbasis multimedia pada pembelajaran tematik subtema perubahan rupa bumi efektif digunakan pada siswa kelas III, karena terdapat peningkatan hasil belajar dilihat dari rata-rata nilai siswa dari 52,56 sampai 67.71 dengan selisih 15,15.

Setelah dilakukan uji $t$, langkah selanjutnya adalah melakukan analisis respon siswa 
Faisal Azmi Bakhtiar, Pengembangan Aplikasi Berbasis Multimedia...

terhadap aplikasi berbasis multimedia pembelajaran tmeatik. Uji tersebut dapat dilihat dari total nilai skala yang diperoleh yaitu 3,19 dan dinyatakan baik, sedangkan jika dilihat dari tiap indikator dapat dilihat pada tabel berikut.

Tabel 9. Respon Siswa Tiap Indikator

\begin{tabular}{lll}
\hline No & Keterangan & Prosentase \\
\hline 1 & Minat Pem. Tematik & $82 \%$ \\
2 & Kegunaan Pem. Tematik & $80 \%$ \\
3 & Minat terhadap Produk & $76 \%$ \\
4 & Kegunaan Produk & $81 \%$ \\
\hline
\end{tabular}

Keterangan prosentase, yaitu: (1) $20 \%$ sangat lemah, (2) $40 \%$ Lemah, (3) $60 \%$ Cukup, (4) $80 \%$ Kuat, dan (5) $100 \%$ Sangat Kuat. Dapat diartikan bahwa minat pembelajaran tematik sangat tinggi, sedangkan untuk kegunaan pembelajaran tematik, minat terhadap produk serta kegunaan aplikasi berbasisi multimedia pembelajaran tematik siswa kelas III Sekolah Dasar tergolong tinggi.

Salah satu hal penting yang perlu dilakukan dalam kegiatan pendidikan disekolah adalah bagaimana membuat kegiatan pembelajaran bisa berjalan secara Aktif, efektif, efisien, dan menyenangkan dalam mencapai tujuan pembelajarannya. Menurut Rončević (2009, p. 237), pada umumnya, sekolah mengajarkan, menguji dan menandai tugas mental logis. Logika, urutan, perhitungan, kategorisasi dan keterampilan verbal di sekolah adalah kemampuan yang sangat dihargai. Intuisi, perasaan, penglihatan, humor, gerakan berirama, imajinasi dan kemampuan otak gestalt lainnya di sekolah tidak dipraktekkan, tidak diuji atau dinilai secara khusus. Hanya di dunia nyata, di luar kelas, di mana kesuksesan bergantung pada kewiraswastaan, imajinasi dan wawasan bahwa kita mulai menghargai pentingnya otak gestalt.

Penggunaan media dalam aktivitas pembelajaran harus dapat memfasilitasi tercapainya kompetensi seperti yang diharapkan oleh para pendidik. Media yang dipilih untuk digunakan dalam aktivitas pembelajaran perlu mempertimbangkan berbagai banyak hal, di antaranya, kurikulum, materi, karakteristik siswa dan juga lingkungan belajar. Dengan demikian, aspek-aspek yang kurang dihargai di sekolah seperti intuisi, perasaan, penglihatan, humor, gerakan berirama, imajinasi dan kemampuan otak gestalt lainnya dapat dikembangkan secara bersamaan di sekolah.

Hasil penelitian ini telah menghasilkan aplikasi berbasis multimedia pada pembelajaran tematik subtema perubahan rupa bumi yang terangkum ke dalam suatu perangkat yang saling berkoordinasi dalam proses pemberian materi, visualisasi, tugastugas, dan evaluasi pada proses kegiatan belajar mengajar. Multimedia pada pembelajaran tematik tersebut juga secara keseluruhan disesuaikan dengan modul yang telah dikembangkan oleh pemerintah sebagai bahan ajar dengan pendekatan tematik. Babiker $(2015$, p. 67) menyebutkan bahwa mengembangkan aplikasi multimedia dapat berkontribusi untuk 
memecahkan beberapa masalah dalam pendidikan, jika pemerintah benar-benar ingin memanfaatkan aplikasi multimedia sebagai alat yang efektif untuk meningkatkan pembelajaran. Hasil uji coba lapangan mengidentifikasi bahwa aplikasi berbasis multimedia pada pembelajaran tematik efektif dan dapat meningkatkan hasil belajar siswa pada subtema perubahan rupa bumi yang dapat dilihat melalui nilai pre-est dan post-test. Hasil tersebut dapat dilihat dari rata rata nilai siswa, yaitu untuk nilai pre-test 52,56 lebih rendah dari nilai pos-test 67,71 dengan selisih 15,15. Hasil pengamatan dan beberapa wawancara insidental menunjukkan bahwa aplikasi berbasis multimedia memberikan motivasi dan menumbuhkan minat belajar siswa pada pembelajaran subtema perubahan rupa bumi kelas III.

Hasil respon siswa juga menunjukkan ratarata nilai skala yaitu 3, 19, masuk pada kategori baik. Sementara itu, jika dilihat dari indikator secara keseluruhan, diperoleh nilai $79,75 \%$ dengan kategori kuat. Hasil analisis respon tersebut dapat diartikan bahwa aplikasi berbasisi multimedia layak diterapkan di Sekolah Dasar kelas III. Hal tesebut sejalan dengan penelitian yang dilakukan oleh Nourmaningrum, Chumdari \& Hartono (2013, p. 6), mereka menyebutkan bahwa terdapat pengaruh positif dalam penggunaan multimedia interaktif. Selain itu, terdapat peningkatan hasil belajar, motivasi yang tinggi kegiatan belajar mengajar lebih menarik, siswa lebih aktif dalam pem-belajaran, hal ini menunjukkan bahwa pembelajaran aktif, inovatif, kreatif, efektif dan menyenangkan (PAIKEM) telah terwujud.

Dalam melakukan proses penelitian dan pengembangan aplikasi berbasis multimedia pada pembelajaran tematik subtema perubahan rupa bumi, memiliki kelebihan dan kekurangan. Kelebihannya yaitu: (1) produk efektif pada ematik di kelas III SD; (2) produk praktis digunakan pada pembelajaran tematik kelas III karena sudah mencakup materi, dan media interaktif yang dapat digunakan oleh guru yang memahami TIK; (3) produk dapat digunakan baik secara individu/ mandiri, atau kelompok sesuai dengan kondisi sarana dan prasarana; (4) produk dilengkapi suara, video, gambar, animasi, teks, kuis, dan permainan sesuai dengan materi, konsep dan tujuan instruksional; (5) produk menggunakan materi yang sesuai dengan buku modul kurikulum 2013; (6) produk disesuaikan pada pendekatan pembelajaran tematik; dan (7) produk menyajikan berbagai kegiatan pembelajaran yang menarik dan menantang bagi siswa.

Sementara itu, kekurangan dari produk ini yang telah diminimalisir antara lain: (1) ketidak sesuaian antara teks dengan suara pada proses penjelasan dalam aplikasi tersebut, namun sudah direvisi dan sudah sesuai; (2) penggunaan karakter yang monoton sudah direvisi menjadi karakter yang beragam; (3) kejelasan suara terletak 
Faisal Azmi Bakhtiar, Pengembangan Aplikasi Berbasis Multimedia...

pada volume yang terlalu rendah sehingga dikhawatirkan siswa tidak dapat mendengarkan, sudah direvisi dan volume sudah dibesarkan; (4) terdapat beberapa petunjuk yang membuat siswa merasa sulit untuk bermain, sudah direvisi dan diminimalisir; dan (5) aplikasi hanya bisa digunakan pada komputer dengan program Microsoft Power Point 2010, 2013, dan 2016. Hal tersebut menjadi kelemahan dan batasan produk ini, namun peneliti berinisiatif untuk memindahkan ke dalam program yang dapat digunakan untuk kapasitas yang lebih luas.

Aplikasi berbasis multimedia pada pembelajaran tematik berimplikasi pada beberapa hal berikut: (1) produk dapat di implementasikan sebagai salah satu media pembelajaran interaktif pada kegiatan pembelajaran tematik di Sekolah Dasar; (2) memperbanyak dan mengintegrasikan media di dalam pembelajaran sehingga dapat menjadi alternatif bahan ajar kedepannya; dan (3) dapat digunakan dan diintegrasikan pada kegiatan belajar mengajar.

\section{SIMPULAN}

Proses penelitian dan pengembangan yang dilaksanakan telah menghasilkan produk berupa desain instruksional dan aplikasi berbasis multimedia pembelajaran tematik. Prosedur pengembangan aplikasi berbasis multimedia pada pembelajaran tematik subtema perubahan rupa bumi terdiri dari langkah-langkah sebagai berikut: (1) melakukan penelitian pendahuluan; (2) membuat perencanaan pengembangan media dengan tahapan dick dan carey; dan (3) melakukan ujicoba dan evaluasi produk untuk mengetahui kelemahankelemahan produk, baik menyangkut desain maupun produk, dimulai dari expert judgment, one to one evaluation, small group, dan field test. Efektivitas aplikasi berbasis multimedia pada pembelajaran tematik subtema perubahan rupa bumi yang dilakukan dengan menganalisis hasil field test data pre-test dan post-test dari 150 responden. Dalam segi efektivitas melalui field test, aplikasi berbasisi multimedia pembelajaran tematik ini dapat dikatakan efektif dengan perhitungan uji- $\dagger$ pada hasil pre-test dan post-test. Selain itu, respon siswa juga menunjukkan baik pada kegiatan pembelajaran tematik dengan bahan ajar multimedia. Berdasarkan hasil pengembangan dengan serangkaian evaluasi dan revisi dari hasil ujicoba baik melalui expert judgement, one to one evaluation, maupun small group evaluation, aplikasi berbasisi multimedia pembelajaran tematik ini dapat dikatakan layak guna dengan kategori baik.

\section{REFERENSI}

Babiker, M. E. A. (2015). For effective use of multimedia in education, teachers must develop their own educational multimedia applications. TOJET: The Turkish Online Journal of Educational Technology, 14(4).

Basri, H. (2013). Landasan Pendidikan. Bandung: Pustaka Setia.

Dick, W., Carey, L., \& Carey, J. O. (2015). The Systematic Design Of Instruction. Florida: Pearson.

Drăghicescu, L. M., Gorghiu, G., Gorghiu, L. M., \& Petrescu, A. M. (2013). Pleading for 
An Integrated Curriculum. Journal of Science \& Arts, 1 (22), 89-95.

Ercan, O. (2014). The Effects of Multimedia Learning Material on Student' Academic Achievement and Attitudes Towards Acience Courses. Journal of Baltic Science Education, 13(5), 608-621.

Gall, M. D., Gall, J. P., \& Borg, W. R. (2007). Educational research: An introduction. New York: Person Education.

Irlidiya, I., Tolla, A., Noni, N., \& Anshari, A. (2015). The development of interactive multimedia for first-grade beginning readers of elementary school: An innovative learning approach. Journal of Language Teaching and Research, 6(3), 553-559.

Muchtarom, M., Budimansyah, D., \& Suryadi, A. (2016). The Implementation of Integrated Education to Develop the Intact Personality of Students. The New Educational Review, 43(1), 147-155. DOI: http://dx.doi.org/10.15804/tner.2016.43.1 $.12 /$.

Munasik, M. (2014). Kemampuan Guru Sekolah Dasar dalam Menerapkan Pembelajaran Tematik di Sekolah. Jurnal Pendidikan, 15(2), 105-113.

Nourmaningrum, D. M., Chumdari., \& Hartono. (2013). Pengaruh Penggunaan Multimedia Interaktif Terhadap Hasil Belajar IPA SD. Surakarta: Universitas Sebelas Maret.

Rončević, A. (2009). Multimedia in primary school. Doctoral dissertation, Pedagoška fakulteta, Univerza $\vee$ Ljubljani.

Sagala, S. (2004). Konsep dan Makna Pembelajaran. Bandung: Alfabeta.

Suwardi, S. (2015). Kendala Implementasi Pembelajaran Tematik di Madrasah Ibtidaiyah Swasta. Prosiding IImu Pendidikan, 1 (2), 267-273.

Unesco. (2017). The four pillars of learning. Tersedia:

http://www.unesco.org/new/en/educati on/networks/globalnetworks/aspnet/about-us/strategy/thefour-pillars-of-learning/.

Wua, L. Y., \& Yamanakab, A. (2013). Exploring the effects of multimedia learning on pre-serviceteachers' perceived and actual learning performance: the use ofembedded summarized texts in educational media. Educational Media International, 50(4), 291-305.
Záhorec, J., Hašková, A., \& Bílek, M. (2014). Impact of Multimedia Assisted Teaching on Student Attitudes to Science Subjects. Journal of Baltic Science Education, 13(3), 361-380. 